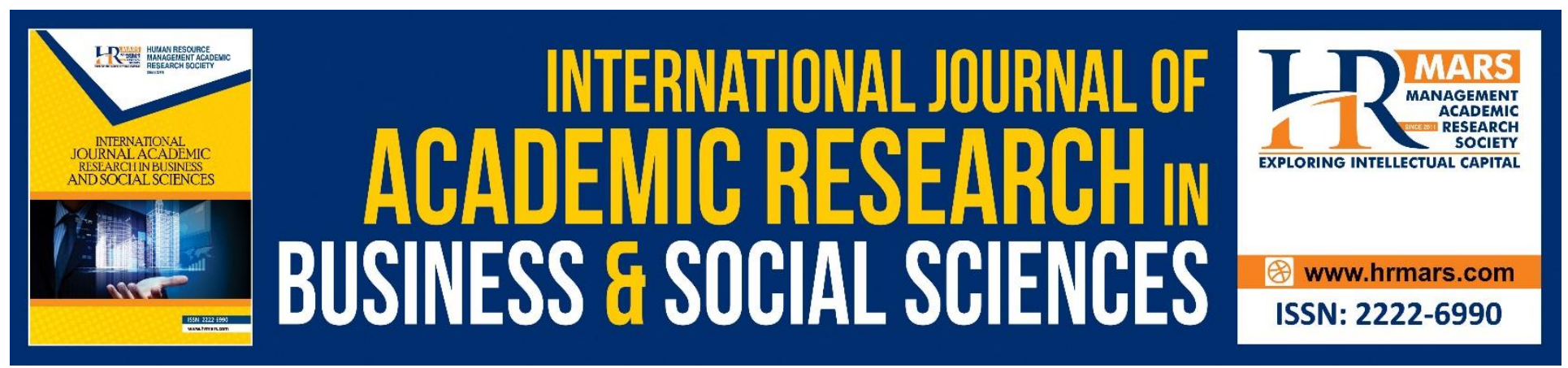

\title{
Collaborative Writing Strategy: CollaboWrite with MindMeister
}

\author{
Alvin Wong, Daisy Kunang Anak Kuah @ Jebi, Yii Hung Ying \\ \& Melor Md Yunus
}

To Link this Article: http://dx.doi.org/10.6007/IJARBSS/v9-i2/5530

DOI: $10.6007 /$ IJARBSS/v9-i2/5530

Received: 02 Jan 2019, Revised: 24 Jan 2019, Accepted: 17 Feb 2019

Published Online: 25 Feb 2019

In-Text Citation: (Wong, Jebi, Ying, \& Yunus, 2019)

To Cite this Article: Wong, A., Jebi, D. K. A. K. @, Ying, Y. H., \& Yunus, M. M. (2019). Collaborative Writing Strategy: CollaboWrite with MindMeister. International Journal of Academic Research in Business and Social Sciences, 9(2), 146-158.

Copyright: @ 2019 The Author(s)

Published by Human Resource Management Academic Research Society (www.hrmars.com)

This article is published under the Creative Commons Attribution (CC BY 4.0) license. Anyone may reproduce, distribute, translate and create derivative works of this article (for both commercial and non-commercial purposes), subject to full attribution to the original publication and authors. The full terms of this license may be seen

at: http://creativecommons.org/licences/by/4.0/legalcode

\section{Vol. 9, No. 2, 2019, Pg. 146 - 158}

Full Terms \& Conditions of access and use can be found at http://hrmars.com/index.php/pages/detail/publication-ethics 


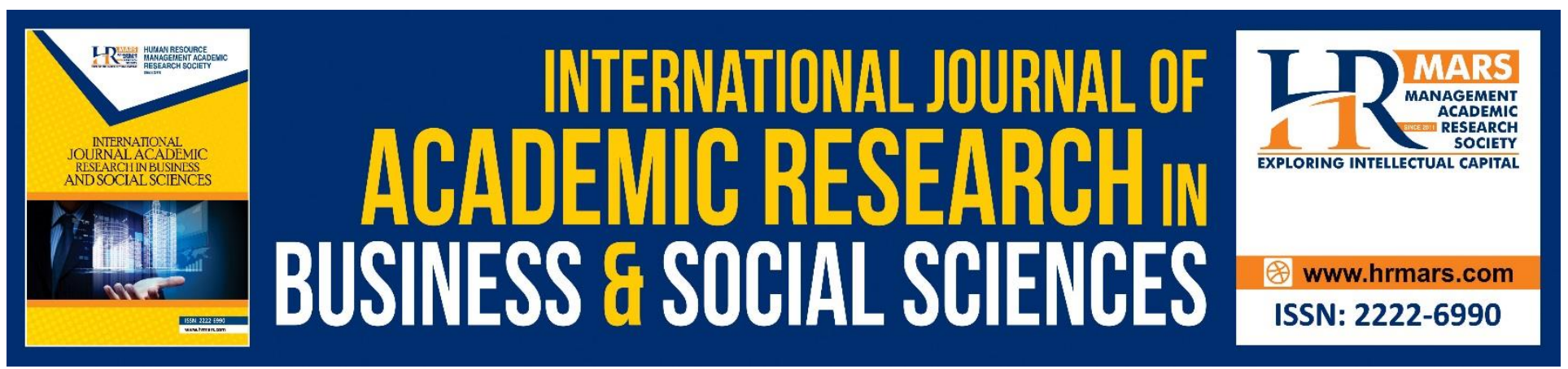

\title{
Collaborative Writing Strategy: CollaboWrite with MindMeister
}

\author{
Alvin Wong ${ }^{1,4}$, Daisy Kunang Anak Kuah @ Jebi ${ }^{2,4}$, Yii Hung Ying 3 \\ \& Melor Md Yunus ${ }^{4}$ \\ SK Batang Lassa, Daro, Sarawak, Malaysia ${ }^{1}$ \\ SK Sungai Penipah, Mukah, Sarawak, Malaysia ${ }^{2}$ \\ SJK(C) Kuen Cheng 1, Kuala Lumpur, Malaysia ${ }^{3}$ \\ Fakulti Pendidikan, Universiti Kebangsaan Malaysia ${ }^{4}$ \\ Email: alvinwong1893@gmail.com², daisyjebi93@gmail.com², angelayiihungying@gmail.com³ \\ melor@ukm.edu.my ${ }^{4}$
}

\begin{abstract}
Malaysian Ministry of Education emphasized on the integration of ICT tools and collaborative learning to enrich the teaching and learning of English language among the English as Second Language (ESL) learners. Among the skills that requires enriching is the writing skill as it is the most challenging language skills which often caused low motivational and proficiency in ESL. Hence, this study introduces a collaborative writing strategy, "CollaboWrite" with the online mind-mapping tool, "MindMeister". In a form of a mixed-method research, this study aimed to gauge the effectiveness of CollaboWrite with MindMeister in developing learners' writing skills in terms of their expression of ideas, collaboration and motivational level. Questionnaires and observation checklists were utilised to collect the data from forty learners of three different schools. This research had unveiled the potential use of CollaboWrite with Mindmeister to facilitate learners' active collaboration in writing and increase their motivation level both in the classroom and through online connection.
\end{abstract}

Keywords: CollaboWrite, MindMeister, Collaboration, Collaborative Writing, Mind Mapping

\section{INTRODUCTION}

In order to reform 21st century learning paradigm, the consolidation of Information and Communication Technology (ICT) into the classroom has become one of the substantial educational prerequisites in the new era of global flows. Lamb, Maire and Doecke (2017) asserted that the education system today should set goals in equipping our young learners with the technological learning tools to mould them into critical thinkers, creative problem solvers and active participants of their communities, away from conventional academic tests and improving their test scores.

Technological learning tools such as Edmodo, Plickers and Kahoot! are great learning 
opportunities that engage and trigger learners' critical thinking, motivation and academic selfconcept. According to Imam (2016), besides the application of educational ICT tools and skills, a collaborative learning atmosphere which focusing on technological integrated learning system should be expanded in a 21st century classroom. This enables the learners to maximise the use of technology while building support for wider community through collaborative and face-to-face online interaction by searching, accessing, interacting, promoting ideas and creativity. According to Luna and Ortiz (2013), it is undeniable that collaborative writing also enhances individual participation, elevates selfconfidence, boosts productivity and leads to fun activities.

It is irrefutable that writing is the most complicated language skills to be learned by ESL learners. This is because writing skills is associated to other language skills and it also requires learners to have extensive grammatical knowledge, appropriate choice of words or phrases, writing mechanics, organizational skills as well as writing styles (Jusun \& Yunus, 2016). Due to learners' apprehension and uncertainty, it is difficult for them to establish their ideas in writing. This is supported by Firmasyah (2013) as major obstacles faced by learners in writing are their ability in generating ideas, difficulty in writing paragraphs and the insufficient vocabulary which lead to encounters in selecting words for writing. Their motivation level to learn is often affected by the difficulty in establishing their ideas as well. According to Hamidun, Hashim and Othman (2012), there is no doubt that motivation is a driving force which allows them to produce meaningful writing and thus become an essential factor to determine successful foreign language acquisition and learning.

With the progression of technology and the fundamentals of collaborative writing strategy, the implementation of CollaboWrite strategy with the online mind-mapping tool, MindMeister can be an educational pedagogical tool to assist the teaching and learning of writing skills. Especially in the context of Teaching English as A Second Language (TESL), the use of technological learning tools with collaborative learning strategies are not something new (Yunus, 2018). Hence, this research had proposed a collaborative writing strategy, the "CollaboWrite" to guide English as Second Language (ESL) learners in reinforcing their writing skills and motivation level through the application of an ICT mind-mapping tool, "MindMeister".

\section{LITERATURE REVIEW}

\section{Past Studies on the Use of Mind Maps to Improve Writing}

Teaching writing skills has always been a tough task for language educators. Unlike other skills such as listening, speaking and reading, mastering writing skills urges an individual to transform ideas and notions into written form by incorporating knowledge on grammar, expression, words choice, point of view and central ideas. Numerous alternatives are constantly being implemented and executed by educators with the aim to develop learners' writing skills. Nurhuda, Yunus and Diyanatul (2017) stated that one of the pertinent techniques to facilitate learners in writing is through mind-mapping due to its ability to stimulate brainstorming process and thus make it possible to produce creative ideas regarding the topic. In conjunction with today's revolutionary trend in education field, mind mapping technique has constantly emerges from conventional into modern style which involves online application. It provides the learners with the opportunities to style, review, revise and save their works (Karim, 2018). Nurhuda et al. (2017) referring to Al-jarf (2009) study on the benefits of mind-map software to practise writing skills also stated that the learners in intervention group display 
progression in terms of organizational skills, generating key points and creating connections between ideas.

\section{Past Studies on the Mind Maps to Improve Collaboration}

Collaborative element has become one of the main emphases in $21^{\text {st }}$ century learning which inspire the learners to work within their group in achieving particular aspirations. Due to demand in the workplace, ability to collaborate with others is among the qualities that is highly desired among the graduates. Chang, Liu, Chen, Huang, Lai and Yeh (2017) stressed on the learners' ability to actively construct knowledge, brainstorm and share ideas with members of the group as the positive influences of collaborative concept mapping strategies. Chang et al. (2017) also further elaborated that through collaboration with other people; learners learn how to comprehend their peers' ideas, thoughts, questions and opinions with their current ideas. Learning writing in foreign language such as English which is challenging, obliges learners to enrol in their active learning. Incorporating mind mapping strategy in collaborative task is able to spark learners' active and student-centred learning (Çoban \& Tokatlı, 2017).

\section{Advantages of Using Mind Mapping for Writing}

Writing process which requires good underpinning of creative and outstanding ideas is indeed a complicated process. As stated by Lim, Yunus and Mohamed Amin (2017), writing process is vital for effective communication which drives learners to carefully sharpen ideas and expressions. Yunus and Chan (2016) stressed on the advantages of mind-mapping in terms of forming ideas excellently, comprehending topic and elaboration of ideas. Budiono, Degeng and Suyitno (2016) drew attention to the relationship between the use of mind mapping and learners' motivation which can be uplifted over time. They also further elaborated that the learners' motivation is high especially when the mind mapping is supplemented with colour and images which results in fun and engaging learning.

\section{METHODOLOGY}

This study had employed a mixed-method research which involved 40 Year 4 pupils of a rural and a sub-urban National School and an urban National Type School in Malaysia. They were selected through purposive sampling with above average proficiency in English Language. Their proficiency level was determined through the School-Based Assessment Report (SBA) and pupils' examination results.

The first step of this study was to introduce the concept of CollaboWrite and the online mindmapping tool, MindMeister to the learners. This was followed by the researchers establishing a similar writing topic and task based on the Year 4 Malaysian English Language textbooks. Then, the participants from all three schools each created a mind map in MindMeister based on the given topic. As sharing session came next, the researchers collected the mind maps from the participants and shared them to the collaborating schools for viewing, feedbacks and improvements in terms of the ideas and points that were placed in the mind map. From the given feedbacks and comments, the creators of the mind maps would note any given details and proceeded with improving their mind map. At the last stage, the participants wrote a paragraph or a short essay based on the mind map as 
the writing activity. These steps were repeated twice throughout the course of the research to reinforce reliability and validity of the collected data.

Throughout the process, the researcher had conducted critical observations by implementing the qualitative measure of observation checklist. The checklist consisted of "Yes" and "No" statements and written remarks for the researchers to take note of any motivation and collaborative engagement in the writing activities. Researcher triangulation were then implemented to identify similarities and differences in the statements, keywords and details of the given remarks.

The researchers had also employed a quantitative measure of survey questionnaire. The survey questionnaire consisted of ten close-ended questions, gauging on the collaboration and motivation aspects and improvement in writing skills. Each item was rated on a Likert scale of 1 to 5 , to indicate the degree of which the participants agree or disagree to any statements based on their experience throughout the implementation of the strategy. As stated by Asún, Rdz-Navarro and Alvarado (2016) and Boone and Boone (2012), descriptive statistics such as mean and standard deviation are suitable to be employed on series of combined questions that measure a particular trait in a Likert scale. Hence, the findings of the survey questionnaire were then analysed through SPSS Version 25 for descriptive statistics involving percentage and mean. In order to identify the participants' level of collaboration, motivation and improvement in writing skills, the mean scores were classified into three levels of class intervals width as proposed by Nunnally and Bernstein (1994). Low level denoted to the mean scores of $1.00-2.33$ while moderate level refers to the mean score of $2.34-3.66$. The high level on the other hand, constitutes the mean scores ranging from $3.67-5.00$.

Both the checklist and questionnaire were constructed to assess and evaluate writing skills and learners' learning motivation with reference to Ahmed (2016) and Pintrich and DeGroot (1990). As conducted in their studies, the Cronbach's alpha coefficient of the questionnaire and checklist had a value of 0.85 , which demonstrated high reliability (Atta, 2018; Hsu, Hwang, \& Chang, 2010; Huang \& Huang, 2015).

\section{FINDINGS AND DISCUSSION}

Table 1 describes the descriptive statistics of the data collected from the survey questionnaire gauging on the collaboration, motivation aspects and improvement in writing skills after the implementation of CollaboWrite with MindMeister. 
Table 1. Data Collected from the Survey Questionnaire $(n=40)$

\begin{tabular}{|c|c|c|c|c|c|c|}
\hline \multirow[b]{2}{*}{ Questions } & \multicolumn{5}{|c|}{ Participants Responses } & \multirow[b]{2}{*}{ Mean Score } \\
\hline & $\begin{array}{l}\text { Strongly } \\
\text { Disagree }\end{array}$ & Disagree & Neutral & Agree & $\begin{array}{c}\text { Strongly } \\
\text { Agree }\end{array}$ & \\
\hline $\begin{array}{l}\text { Q1 I like writing activities even before I } \\
\text { learn through CollaboWrite with } \\
\text { MindMeister. }\end{array}$ & $\begin{array}{c}4 \\
(10 \%)\end{array}$ & $\begin{array}{c}2 \\
(5 \%)\end{array}$ & $\begin{array}{c}13 \\
(32 \%)\end{array}$ & $\begin{array}{c}14 \\
(35 \%)\end{array}$ & $\begin{array}{c}7 \\
(18 \%)\end{array}$ & $\begin{array}{c}3.45 \\
\text { (Moderate) }\end{array}$ \\
\hline $\begin{array}{l}\text { Q2 I like to work with my friends when } \\
\text { doing writing activities even before I } \\
\text { learn through CollaboWrite with } \\
\text { MindMeister. }\end{array}$ & $\begin{array}{c}1 \\
(2 \%)\end{array}$ & $\begin{array}{c}5 \\
(12 \%)\end{array}$ & $\begin{array}{c}5 \\
(13 \%)\end{array}$ & $\begin{array}{c}14 \\
(35 \%)\end{array}$ & $\begin{array}{c}15 \\
(38 \%)\end{array}$ & $\begin{array}{c}3.93 \\
\text { (High) }\end{array}$ \\
\hline $\begin{array}{l}\text { Q3 I think using Collabo Write technique } \\
\text { improves my paragraph writing. } \\
\text { Q4 I think using mind map in }\end{array}$ & $\begin{array}{c}1 \\
(2 \%)\end{array}$ & $\begin{array}{c}2 \\
(5 \%)\end{array}$ & $\begin{array}{c}6 \\
(15 \%)\end{array}$ & $\begin{array}{c}14 \\
(35 \%)\end{array}$ & $\begin{array}{c}17 \\
(43 \%)\end{array}$ & $\begin{array}{c}4.10 \\
\text { (High) }\end{array}$ \\
\hline $\begin{array}{l}\text { MindMeister helps me to map and } \\
\text { categorize my ideas better for writing } \\
\text { activities. }\end{array}$ & $\begin{array}{c}1 \\
(2 \%)\end{array}$ & $\begin{array}{c}4 \\
(10 \%)\end{array}$ & $\begin{array}{c}4 \\
(10 \%)\end{array}$ & $\begin{array}{c}17 \\
(43 \%)\end{array}$ & $\begin{array}{c}14 \\
(35 \%)\end{array}$ & $\begin{array}{c}3.98 \\
\text { (High) }\end{array}$ \\
\hline $\begin{array}{l}\text { Q5 I can collaborate to give ideas and } \\
\text { positive comments while doing writing } \\
\text { activities through CollaboWrite with } \\
\text { MindMeister }\end{array}$ & $\begin{array}{c}3 \\
(7 \%)\end{array}$ & $\begin{array}{c}6 \\
(15 \%)\end{array}$ & $\begin{array}{c}3 \\
(7 \%)\end{array}$ & $\begin{array}{c}11 \\
(28 \%)\end{array}$ & $\begin{array}{c}17 \\
(43 \%)\end{array}$ & $\begin{array}{c}3.83 \\
\text { (High) }\end{array}$ \\
\hline $\begin{array}{l}\text { Q6 I think my collaborative skill } \\
\text { improves after learning through } \\
\text { CollaboWrite with MindMeister. }\end{array}$ & $\begin{array}{c}0 \\
(0 \%)\end{array}$ & $\begin{array}{c}3 \\
(7 \%)\end{array}$ & $\begin{array}{c}4 \\
(10 \%)\end{array}$ & $\begin{array}{c}15 \\
(38 \%)\end{array}$ & $\begin{array}{c}18 \\
(45 \%)\end{array}$ & $\begin{array}{c}4.20 \\
\text { (High) }\end{array}$ \\
\hline $\begin{array}{l}\text { Q7 I find that doing writing activities } \\
\text { take less time through CollaboWrite } \\
\text { with MindMeister. }\end{array}$ & $\begin{array}{c}3 \\
(7 \%)\end{array}$ & $\begin{array}{c}6 \\
(5 \%)\end{array}$ & $\begin{array}{c}7 \\
(17 \%)\end{array}$ & $\begin{array}{c}17 \\
(43 \%)\end{array}$ & $\begin{array}{c}7 \\
(18 \%)\end{array}$ & $\begin{array}{c}3.48 \\
\text { (Moderate) }\end{array}$ \\
\hline $\begin{array}{l}\text { Q8 I think I can write with more details } \\
\text { after learning through CollaboWrite } \\
\text { with MindMeister. }\end{array}$ & $\begin{array}{c}0 \\
(0 \%)\end{array}$ & $\begin{array}{c}2 \\
(5 \%)\end{array}$ & $\begin{array}{c}12 \\
(30 \%)\end{array}$ & $\begin{array}{c}13 \\
(32 \%)\end{array}$ & $\begin{array}{c}13 \\
(33 \%)\end{array}$ & $\begin{array}{c}3.93 \\
\text { (High) }\end{array}$ \\
\hline $\begin{array}{l}\text { Q9 I had fun while learning to write } \\
\text { through CollaboWrite with } \\
\text { MindMeister because it is simple and } \\
\text { easy to use. }\end{array}$ & $\begin{array}{c}1 \\
(2 \%)\end{array}$ & $\begin{array}{c}1 \\
(2 \%)\end{array}$ & $\begin{array}{c}3 \\
(8 \%)\end{array}$ & $\begin{array}{c}9 \\
(23 \%)\end{array}$ & $\begin{array}{c}26 \\
(65 \%)\end{array}$ & $\begin{array}{c}4.45 \\
\text { (High) }\end{array}$ \\
\hline $\begin{array}{l}\text { Q10 I would like to use CollaboWrite } \\
\text { with MindMeister for my future writing } \\
\text { activities. }\end{array}$ & $\begin{array}{c}2 \\
(5 \%)\end{array}$ & $\begin{array}{c}3 \\
(7 \%)\end{array}$ & $\begin{array}{c}2 \\
(5 \%)\end{array}$ & $\begin{array}{c}14 \\
(35 \%)\end{array}$ & $\begin{array}{c}19 \\
(48 \%)\end{array}$ & $\begin{array}{c}4.13 \\
\text { (High) }\end{array}$ \\
\hline
\end{tabular}


As illustrated in Table 1, Questions 1, 9 and 10 targeted on the participants' motivational level, while Questions 2, 5 and 6 focused on the participants' collaborative skills throughout CollaboWrite with MindMeister. On the other hand, Questions 3, 4, 7 and 8 emphasized on the improvement in writing skills after the implementation of CollaboWrite with MindMeister.

Based on the motivational level through the implementation of CollaboWrite with MindMeister, $88 \%$ of the participants agreed to the aspect of "I had fun and enjoy myself while learning to write through CollaboWrite with MindMeister because it is simple and easy to use" while 83\% agreed to the statement "I would like to use CollaboWrite with MindMeister for my future writing activities". Both of the statements scored a high mean level of 4.45 and 4.13 respectively. On the contrary, only 53\% agreed as per the statement "I like writing activities even before I learn through CollaboWrite with MindMeister." with a moderate mean level of 3.45. These three statements highlighted that learners were highly motivated while working on CollaboWrite with MindMeister as compared to conventional writing activities.

On the aspects of collaboration, $71 \%$ of the participants agreed to the statement "I can collaborate to give ideas and positive comments while doing writing activities through CollaboWrite with MindMeister" while 83\% agreed to the aspect of "I think my collaborative skill improves after learning through CollaboWrite with MindMeister". Both of these scored a high level mean of 3.83 and 4.20. On the same aspect, $73 \%$ of the participants agreed to "I like to work with my friends when doing writing activities even before I learn through CollaboWrite with MindMeister" with a high mean score of 3.93. These statements showed that the participants were willing to collaborate with their peers for writing activities and the collaboration aspect was further enhanced with the use of CollaboWrite with MindMeister.

For the aspect of improvement in writing skills, three of the four statements which are "I think using CollaboWrite technique improves my paragraph writing.", "I think using mind map in MindMeister helps me to map and categorize my ideas better for writing activities." and "I think I can write with more details after learning through CollaboWrite with MindMeister." scored a high mean of 4.10, 3.98 and 3.93 respectively. These showed that with the application of CollaboWrite with MindMeister, the participants were able to write paragraphs or short essays better as ideas and feedbacks were given to improve their writing. Nevertheless, for the statement "I find that doing writing activities take less time through CollaboWrite with MindMeister." only a moderate score of 3.48 was procured. For some of the participants, writing activities through CollaboWrite with MindMeister may take longer time to complete as the process was limited by factors of internet speed, connectivity and availability of computer.

All in all, the total mean scores of 3.95 (high level) for all 10 items from the survey questionnaire indicated that the learners gained positive and constructive experiences in applying CollaboWrite in a form of mind map through MindMeister. 
Table 2. Data Collected from the Triangulated Observation Checklist

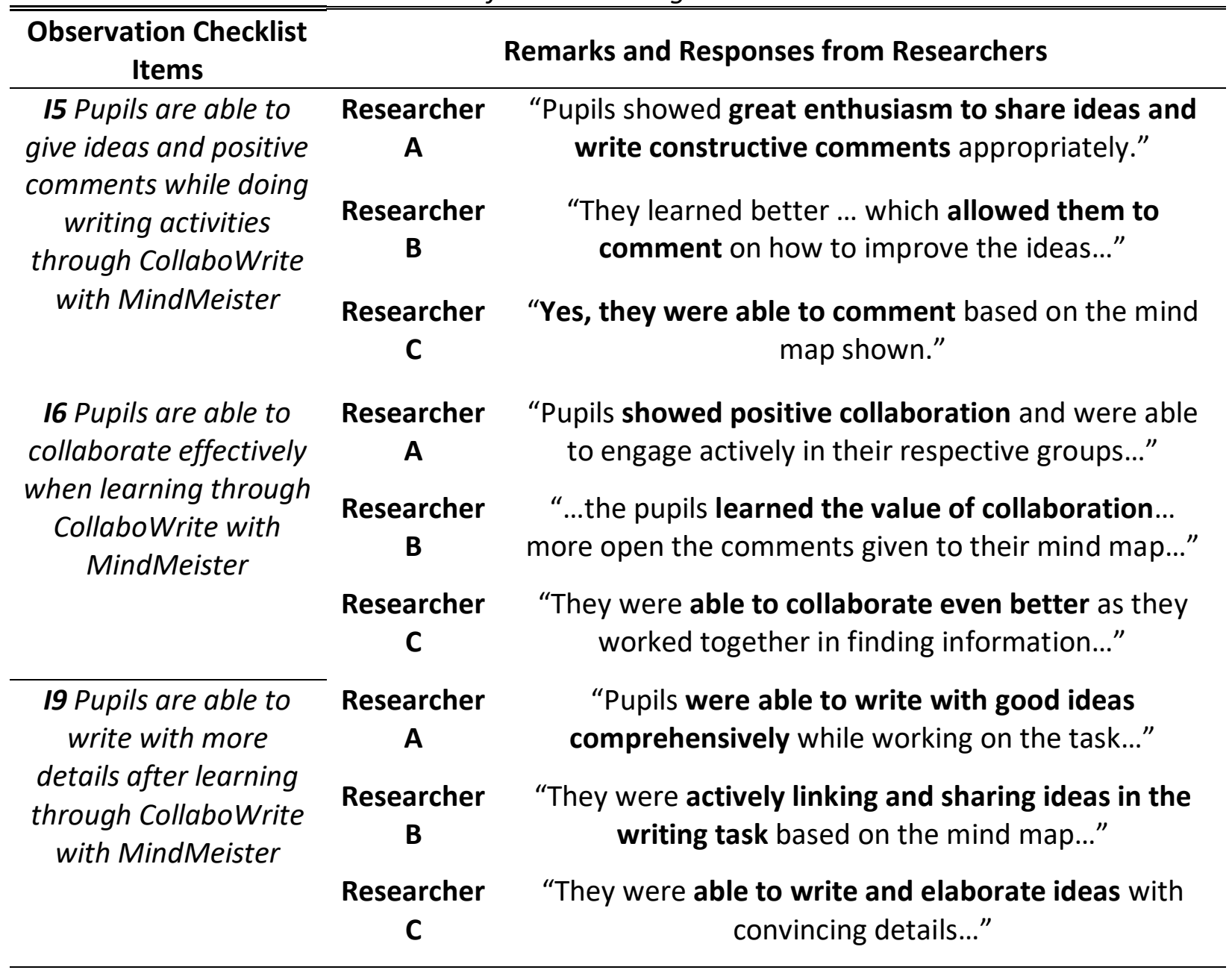

The observation checklists on the other hand were triangulated between three researchers of the three different schools. As emphasized in Item 5, 6 and 9 in the checklist, the researchers agreed that to the items "Pupils are able to give ideas and positive comments while doing writing activities through CollaboWrite with MindMeister", "Pupils are able to collaborate effectively when learning through CollaboWrite with MindMeister" and "Pupils are able to write with more details after learning through CollaboWrite with MindMeister". From the agreed statements, the learners involved in this research were able to collaborate effectively within their groups to produce constructive comments and write-ups to their peers of different schools within the network. Thus, in a nutshell, CollaboWrite with MindMeister had achieved its potential in encouraging pupils to improve their writing skills collaboratively.

\section{IMPLICATIONS}

Through the study, Collabowrite with MindMeister had successfully enhanced learners' ideas and writing skills via emphasis on written key words, presenting images, colourful words and map connections. Compared to solely written words, Collabowrite with MindMeister had greatly assisted 
the learners not only to systematically organise important key points better, but also heightened the visualization of ideas and important phrases for writing. According to Marashi and Kangani (2018) shaping better writers has also become less laborious as the mind map illustrates the connections of ideas to link their sentences. The constructive feedbacks given by their peers and teachers from different schools had also reinforced the development and connection of ideas among the learners. Learners' opportunity to organise their ideas creatively and freely unlike the linear thinking produces authentic writing which reflects the learners' way of thinking (Wette, 2017). Hence, it was seen that Collabowrite with MindMeister had strengthened the learners' ideas and the ability to construct proper sentence structures for better quality of their good piece of writing.

According to Vygotsky Theory as cited by Clarà (2017), social interaction is a crucial element in contributing to individuals' cognitive development. Social interaction in learning activities such as group works and team project reports empower the learners and assist them in the course of gaining knowledge and skills collaboratively. Working in a group not only promotes communication and cooperation among members but also enables the learners to learn together as a team (Zakaria, Yunus, Nazri, \& Shah, 2016). The authenticity of CollaboWrite with MindMeister had effectively created a great opportunity for the learners to cooperate and collaborate. This had provided a different platform and learning experience to learners as they need to listen to others' views, clarify their own ideas, evaluate on the given written tasks and arrive at a consensus on certain writing opinions.

Kwan and Yunus (2017) affirms that collaborative writing is a creative pedagogical tool that provides a highly motivating learning experience to ESL learners as it promotes individual participation, increases self-confidence, encourages productivity and makes the writing activities fun and meaningful. CollaboWrite with MindMeister is a motivational strategy because the learners involved in this strategy developed the ability to motivate themselves in regulating their learning process. This could be seen when the learners felt motivated as their mind maps and writing products were being shared and constructively commented by collaborating peers from different schools. This is supported by Chang, Lee, and Chen (2016) as sharing one learning products with collaborating peers elevates learners' interest and motivational level to work hard in the future.

Therefore, CollaboWrite with MindMeister could provide ESL learners with an enriching 21st century real-life networking that serves as a collaborative platform to increase their motivational level in improving their writing skills and a dynamic pedagogical tool to assist ESL educators in the teaching of writing skills.

\section{CONCLUSION}

With reference to the findings collected in this study, CollaboWrite with MindMeister had brought positive impacts towards the learners in which the total mean scores of 3.95 (high level) for all 10 items from the survey questionnaire proved that the participants enjoyed themselves while learning to write with CollaboWrite with MindMeister, their collaborative skills had also improved when they engaged actively with their friends in learning and the ideas as well as feedbacks gained were also able to help them in improving their paragraph writing. Hence, CollaboWrite with MindMeister had initiated a positive and interactive learning climate in which the learners from different schools assisted and supported each other in improving their writing abilities. Besides facilitating learners' 
active collaboration, CollaboWrite with MindMeister had successfully increased their motivation level in participating themselves in writing activities. Furthermore, CollaboWrite with MindMeister had offered a platform in exposing learners to real life exploration and networking while cultivating a culture of respect.

However, based on the results of this research, it was found out that CollaboWrite with MindMeister was a bit time consuming. In order to conduct a better study in the future, it is suggested that a few ready-made templates can be set earlier so that the learners can choose a variety of ready templates to work on directly without starting from the scratch and this would take lesser time for them to accomplish their work effectively. Besides, instead of limiting to group work based study, this research can also be conducted in the classroom as a whole classroom project. This is where the researchers can divide the learners into small groups in which every group is responsible to create a small section of the topic collaboratively. At the end of the project, the mind maps of each group will be combined into a larger mind map for the learners to refer. This will enable the learners to get learning support through interaction with a wider community and this has eventually enhanced their interpersonal skills. A healthy learning culture with the value of respect and the involvement of different cultures will also be instilled.

All in all, this research is hoped to ring up the curtain to school teachers in Malaysia as to embrace the incorporation of technology and collaborative learning in the 21st century teaching and learning classroom.

\section{REFERENCES}

Ahmed, M. A. E. A. S. (2016). The Effect of a Flipping Classroom on Writing Skill in English as a Foreign Language and Students' Attitude Towards Flipping. US-China Foreign Language, 14(2), 98-114. https://doi.org/10.17265/1539-8080/2016.02.003

Al-jarf, R. (2009). Enhancing Freshman students' Writing Skills with a Mind Mapping Software. In eLearning and Software for Education (pp. 3-10). Bucharest.

Asún, R. A., Rdz-Navarro, K., \& Alvarado, J. M. (2016). Developing Multidimensional Likert Scales Using Item Factor Analysis: The Case of Four-point Items. Sociological Methods \& Research, 45(1), 109-133. https://doi.org/10.1177/0049124114566716

Atta, A. M. S. S. (2018). Engaging ESP University Students in Flipped Classrooms for Developing Functional Writing Skills, HOTs, and Eliminating Writer's Block. English Language Teaching, 11, 177. https://doi.org/10.5539/elt.v11n12p177

Boone, H. N., \& Boone, D. (2012). Analyzing Likert Data. Journal of Extension, 50(2).

Budiono, I. A., Degeng, N. S., \& Suyitno, I. (2016). Short Story Learning Skills In Indonesian Subject The Effect of Mind Mapping Method And Learning Motivation on Writing Short Story Learning Skills In Indonesian Subject. IOSR Journal of Research \& Method in Education (IOSR-JRME), 6(5), 109112. https://doi.org/10.9790/7388-060501109112 
Chang, C.-C., Liu, G.-Y., Chen, K.-J., Huang, C.-H., Lai, Y.-M., \& Yeh, T.-K. (2017). The Effects of a Collaborative Computer-based Concept Mapping Strategy on Geographic Science Performance in Junior High School Students. EURASIA Journal of Mathematics Science and Technology Education, 13(8), 5049-5060. https://doi.org/10.12973/eurasia.2017.00981a

Chang, L.-Y., Lee, I.-H., \& Chen, C.-H. (2016). Effects of an Intercultural Collaborative Inquiry Approach on Students' Learning Strategies and Motivation and Perceptions of Collaboration. In The International Workshop on Technology - Enhanced Collaborative Learning (TECL 2016) (pp. 1821).

Clarà, M. (2017). How Instruction Influences Conceptual Development: Vygotsky's Theory Revisited. Educational Psychologist, 52(1), 50-62. https://doi.org/10.1080/00461520.2016.1221765

Çoban, S., \& Tokatlı, E. S. (2017). The Effect of Mind Mapping Technique on Students' Achievements in Music Lesson and on Their Attitudes towards the Mind Mapping Technique. Education and Science, 42(190), 423-435. https://doi.org/10.15390/EB.2017.6856

Firmasyah, A. (2013). The Influence of Mind Mapping Technique and Students ' Attitude toward Students ' Ability in Writing a Recount Text of the Eighth Grade Students of State Junior High School 45 Palembang. Jurnal Ilmu Pendidikan Dan Kajian Pengajaran Universitas PGRI Palembang, 2(1), 11-18.

Hamidun, N., Hashim, S. H., \& Othman, N. F. (2012). Enhancing Students' Motivation by Providing Feedback on Writing: The Case of International Students from Thailand. International Journal of Social Science and Humanity, 2(6), 2-5. https://doi.org/10.7763/IJSSH.2012.V2.179

Hsu, C. K., Hwang, G. J., \& Chang, C. K. (2010). Development of a Reading Material Recommendation System Based on a Knowledge Engineering Approach. Computers \& Education, 55(1), 76-83.

Huang, Y. M., \& Huang, Y. M. (2015). A Scaffolding Strategy to Develop Handheld Sensor-Based Vocabulary Games for Improving Students' Learning Motivation and Performance. Educational Technology Research and Development, 63(5), 691-708. https://doi.org/10.1007/s11423-0159382-9

Imam, M. F. (2016). Developing The 21st-Century Social Studies Skills Through Technology Integration. Turkish Online Journal of Distance Education-TOJDE, 17(January), 16-30.

Jusun, K. D., \& Yunus, M. M. (2016). The Effectiveness of Using Sentence Makers in Improving Writing Performance among Pupils in Lubok Antu Rural Schools. In International Conference on Education (pp. 469-475). 
Karim, R. A. (2018). Technology-Assisted Mind Mapping Technique in Writing Classrooms: An Innovative Approach. International Journal of Academic Research in Business and Social Sciences, 8(4), 1092-1103. https://doi.org/10.6007/IJARBSS/v8-i4/4146

Kwan, L. S. L., \& Yunus, M. M. (2017). Group Participation and Interaction in ESL Wiki Collaborative Writing among Malaysian Gifted Students. Asian Social Science, 11(2), 59-68. https://doi.org/10.5539/ass.v11n2p59

Lamb, S., Maire, Q., \& Doecke, E. (2017). Key Skills for the 21st Century: An evidence-based review. Sydney: NSW Department of Education. Retrieved from http://vuir.vu.edu.au/35865/

Lim, K. I., Yunus, M. M., \& Embi, M. A. (2017). Build Me Up : Overcoming Writing Problems Among Pupils In A Rural Primary School In Belaga, Sarawak, Malaysia. Jurnal Pendidikan Humaniora, 5(1), 1-7.

Luna, A. M. R., \& Ortiz, L. S. H. (2013). Collaborative Writing to Enhance Academic Writing Development Through Project Work. HOW, A Colombian Journal for Teachers of English, 2(1), 130-148.

Marashi, H., \& Kangani, M. (2018). Using Concept Mapping and Mind Mapping in Descriptive and Narrative Writing Classes. Journal of Language and Translation, 8(2), 93-106.

Nazri, N. M., Yunus, M. M., \& Shukor, D. M. A. (2017). The Effectiveness of using Mindomo as a PreWriting Tool in Improving Writing Scores among ESL Students. Asian EFL Journal, 9, 84-94.

Nunnally, J. C., \& Bernstein, I. . (1994). The Assessment of Reliability. Psychometric Theory, 3, 248292.

Pintrich, R. R., \& DeGroot, E. V. (1990). Motivational and Self-Regulated Learning Components of Classroom Academic Performance. Journal of Educational Psychology, 82, 33-40.

Wette, R. (2017). Using mind maps to reveal and develop genre knowledge in a graduate writing course. Journal of Second Language Writing, 38(December), 58-71. https://doi.org/https://doi.org/10.1016/j.jslw.2017.09.005

Yunus, M. M. (2018). Innovation in Education and Language Learning in 21st Century. Journal of Sustainable Development Education and Research, 2(1), 33-34.

Yunus, M. M., \& Chan, H. C. (2016). The Use of Mind Mapping Strategy in Malaysian University English Test (MUET) Writing. Creative Education, 7(January), 619-626. https://doi.org/10.4236/ce.2016.74064 
International Journal of Academic Research in Business and Social Sciences

Vol. 9, No. 2, Feb, 2019, E-ISSN: 222 2-6990 @ 2019 HRMARS

Zakaria, S. M., Yunus, M. M., Nazri, N. M., \& Shah, P. (2016). Students' Experience of Using Storybird in Writing ESL Narrative Text. Creative Education, 07, 2107-2120. https://doi.org/10.4236/ce.2016.715210 